\title{
EchoGéo
}

$53 \mid 2020$

Dénominations plurielles. Quand les noms de lieux se concurrencent

\section{"We shall know a place by its names": Co-existing place names in Bindura, Zimbabwe}

Dorcas Zuvalinyenga

\section{(2) OpenEdition}

Journals

Electronic version

URL: https://journals.openedition.org/echogeo/20057

DOI: $10.4000 /$ echogeo.20057

ISSN: 1963-1197

Publisher

Pôle de recherche pour l'organisation et la diffusion de l'information géographique (CNRS UMR 8586)

Electronic reference

Dorcas Zuvalinyenga, "'We shall know a place by its names": Co-existing place names in Bindura, Zimbabwe", EchoGéo [Online], 53 | 2020, Online since 10 December 2020, connection on 10 August 2021. URL: http://journals.openedition.org/echogeo/20057 ; DOI: https://doi.org/10.4000/echogeo 20057

This text was automatically generated on 10 August 2021

EchoGéo est mis à disposition selon les termes de la licence Creative Commons Attribution - Pas d'Utilisation Commerciale - Pas de Modification 4.0 International (CC BY-NC-ND) 


\title{
"We shall know a place by its names": Co-existing place names in Bindura, Zimbabwe
}

\author{
Dorcas Zuvalinyenga
}

\section{Introduction}

1 Toponymy, defined as "a science encompassing the study of geographical names" (Woodman 2012, p. 5) can facilitate important and complex associations and semantic prosodies. For instance, whenever Robert Gabriel Mugabe Street or Robert Gabriel Mugabe International Airport is mentioned associations with Zimbabwe, panAfricanism, hyperinflation, and the land reform, among other things, may arise, in part due to the "image" of Zimbabwe built up in the public consciousness following decades of international media coverage. Place names can be intricately connected to a place's and its people's identity. The interconnections between place naming, identity and geopolitics is now an established fact in critical toponymy (Rose-Redwood, Alderman et Azaryahu, 2009, 2017; Rose-Redwood et al., 2019) and linguistic landscape (LL) studies (Ben-Rafael, 2008; Shohamy, 2006; Shohamy et Gorter, 2008; Shohamy et al., 2010). Research in these fields shows that assigning names to features acts as assertions of political power over space and a key component for building spatial identities. Thus, place naming serves the dual purposes of making it possible to identify a location while simultaneously creating a socio-cultural scene that overtly memorializes historical figures, events, places and ideals. In the same analysis, place naming is linked to structures of power and discourses of identity making it a possibly contested spatial practice that results in multiple and competing place names (Rose-Redwood et Kim, 2020). Toponymic inscription, the exercise of place naming, has been seen to be a tool for articulating power in places like Senegal and Kenya ( $c f$. Njoh 2016). Finally, Tucci, Ronza, and Giordano, 2011) point out in their study of what they call the "layering (of) the toponymic tapestry". Toponyms can be a reflection of a place's long and contested social and political history where fragments "of all the different toponymic regimes 
and hegemonic discourses that took over one after the other over time" will remain inscribed, thus originating "a complex tapestry in which different pasts revive and conflicting ideologies co-exist" (Tucci et al., 2011, p. 370).

When wishing to specify a particular feature or place, "we may find that there are several names available for it" (Woodman 2012, p.5). The phenomenon of plural toponymies reflects both the simultaneous use and co-existence of place names. Basically, a place can - for a variety of reasons - be known by more than one name. This simultaneous use and co-existence can be harmonious, ambivalent or uneasy. Studies of plural toponymies, however, tend to be few and far between, more so in small towns or rural areas. The location of the study is Bindura, a farming and mining town of some 46,275 people (Zimbabwe Statistical Agency, 2015) in the Mashonaland Central province of Zimbabwe. The governmental capital of the province, Bindura is located some $88 \mathrm{~km}$ northeast of Harare. Bindura's selection as a case study highlights Azaryahu's (1996, $2009,2011)$ contention that most research tends to focus on larger cities at the expense of the smaller towns and scholarship may be missing out on what can be found in these smaller cities. This study thus sought to fill this gap. That is, the study focuses on Bindura because it is a regional town that is neglected (Helliker et Bhatasara, 2018; Helliker, Chiweshe, et Bhatasara, 2018) compared to the bigger cities such as Harare, Bulawayo, Masvingo and Mutare. This neglect is seen in terms of both economic and social development where essential services can only be found in Harare. In addition, because administration of the town is from the central government, it is likely that toponymic trends in Bindura may be representative of what prevails in the country as noted by Mangena, 2018). There is also no specific research report on the languages spoken in the area and the distribution of the speakers other than those that focus on the whole country (Kadenge et Mugari, 2015; Mlambo, 2009). The absence of such research further justifies this project.

Drawing from and expanding on the insights made in critical toponymy and linguistic landscape studies, this article addresses the following research questions:

- How are place name variants connected to their geopolitical communities?

- What implications do plural toponymies have on members of a community and their relationship to a place?

- What are the discourses, ideologies, identities and social representations being revealed by variant place names?

\section{Methodology}

4 The title of the article draws from Firth's (1957, p. 11) proposition that "you shall know a word by the company it keeps" which implies distributional approaches to word meanings. Firth suggests collocation analysis to determine word meanings, where the co-occurrence of particular words can point to their syntagmatic meaning. For example, one of the meanings of night can be noted from its tendency of co-occurring with dark and vice versa. This notion of collocation, albeit in a different and simplified context, has been adapted in this article to refer to what it can contribute to understanding plural toponymic discourses. In this sense, place names and their use are considered as discourses that can be useful in revealing and understanding ideologies, identities and messages carried in multiple place naming practices, because word co-occurrence may shed new light on multifaceted webs of identities, discourses 
and social representations in a given society (Bogetić, 2013). It is proposed that names and naming practices of a place give us windows into the events or behaviours of a particular place and its inhabitants. Context matters, in particular "context as understood, received and accepted by the social grouping bearing witness" to the name (Woodman, 2012, p. 12). These events and behaviours are traced from precolonial times to the present and include but are not limited to history, culture, identities, gender or class relations, power and communication.

Most research in critical toponymy and linguistic landscape (LL) generally pays insufficient attention to the phenomenon of multiple toponymies and its effects in naming practices and societies (Rose-Redwood et al., 2018; Shohamy et al., 2010). Therefore, this study analyses reasons that necessitate plural toponymic practices as well as their effects and functions on identity construction/constraining and power relations in a multilingual, multicultural society like Bindura, Zimbabwe. Bindura as a regional town that has a rural hinterland has not featured much in Zimbabwean toponomastics. Essentially, most Zimbabwean toponymy focus on bigger cities such as Harare, Bulawayo, Masvingo and Mutare (Dube, 2018; Mamvura, 2014; Mamvura, Mutasa, et Pfukwa, 2017; Mushati, 2013; Nyambi, Mangena, et Pfukwa, 2016; Pfukwa, 2018) while other studies examine the phenomenon in the global north (Ameel et Ainiala, 2018; Rose-Redwood et al., 2018).

6 Semi-structured interviews with a range of participants from planning officials, public transport drivers, conductors and users, youths and the elderly inhabitants of the area were carried out $(\mathrm{n}=35)$, including surveys, observations, as well as analysis of documents such as maps, gazetteers, archives and reports. The discourse-historical approach (DHA) of Critical discourse analysis (CDA), was used to analyse these "texts" because of its utility in explicating power relationships embedded in everyday conversations such as naming places and using those names (Wodak, 2015). Bindura is a town on the margins, and provisions in CDA encourage giving voice to such. The DHA also emphasizes consideration of the linguo-socio-cultural-historical context of the phenomena under investigation. This position enables a researcher to grasp the bigger picture of the subject while becoming aware of the intertextuality of place naming practices. A place name is not an isolated form of spatial reference but is related to other names within and or outside the particular area, other socio-economic issues prevailing in the immediate community, the nation or at an international scale (Ainiala et Östman, 2017). Further to that, the DHA provides directions in undertaking an analysis as long as the context is clarified. This approach to language analysis has adopted a common set of guiding principles, assumptions and perspectives that are diverse, complementary but sometimes competing, making it flexible and usable.

Critical discourse analysis articulates well the study of identity and multiple place naming. Identity is important in place naming because it connects individuals with groups. This allows us to understand how individuals associate with or detach themselves from certain communities, the type of information they intend to express about themselves and how this information in turn mirrors the ideas others hold about them. Hodge (2012) argues that when speaking about a place name, speakers are always making choices about how to index a location. Such choices tell us something about speaker intentions and the nature of the commitment they have to the proposition expressed with the use of a particular toponym. In this sense, identity becomes vital in transmitting "to one another what kind of people we are; which geographical, ethnic, 
social communities we belong to; where we stand in relation to ethical and moral questions; or where our loyalties are in political terms" (De Fina, 2006, p. 263). Understood this way, identity then relates with the view that language use, in our case multiple place naming, is not only a cognitive venture, but also similarly an inherently social one. The foregoing's understanding of identity makes us think about the motives for and the circumstances under which people name places, the ways they are viewed by other users of toponyms, the implications they want to convey in certain situations and the resources they draw upon in order to do so (Zotzmann et O'Regan, 2016).

Identity is a conversational phenomenon because the way individuals and others portray themselves is developed through language and other semiotic resources. It is additionally material because people take up identities in relation to contexts. It is performed in time and space, in actual settings and as an outcome of actual circumstances. Individuals perform acts of identity such as choosing to use a slang toponym over an official one or take a selfie next to particular signage depending on the context (Zuvalinyenga, 2020). However, individuals do not perform these acts of identities on the same terms because inter-individual experiences vary, as do their social positions, related access to linguistic, cultural, economic, and other resources social and material - that grant them different degrees of recognition. Significantly, Zotzmann and O'Regan (2016) make it apparent that categorizations of self and other are influenced by discourses about social groups that are produced and re-produced at different levels of society and in different social spheres such as the media, education and politics. These conversations, in turn, are affected by and affect social hierarchies in a variety of ways. Therefore, because identity constructions are pervaded with power relations and ideology that can be exposed through a critical discourse analysis, the framework has thus been chosen.

9 A review of related literature together with definitions of key terms is presented, followed by a background which contextualises the case study the theoretical framework, methods the results discussion of research findings, and the conclusion.

\section{Review of related literature}

Literature from critical toponymy, linguistic landscape studies, critical discourse studies and sociolinguistics was consulted to explore how multiple place names are connected and the implications arising from these connections. Further, the discussion explores the various discourses, ideologies, identities and social representations being revealed by these variant and plural place names or practices.

\section{The critical turn in place name studies}

11 Critical toponymic enquiry is a developing field deserving further research (Azaryahu, 2011; Berg et Vuolteenaho, 2009; Bigon, 2008; Bigon, 2016; Górny et Górna, 2019a, 2019b; Njoh, 2007; Njoh, 2009; Puzey et Kostanski, 2016; Rose-Redwood et al., 2009, 2017; Sihlongonyane, 2015; Wanjiru et Matsubara, 2017). Critical name studies, according to Puzey and Kostanski, 2016) react to sentiments expressed by many scholars' citation of the utterances: "A rose by another name would still smell as sweet" from Shakespeare's seminal Romeo and Juliet. The saying conveys the idea that names merely label objects they denote. Critical toponymic studies problematize such assumptions by highlighting 
symbolic functions of naming. Giraut and Houssay-Holzschuch (2016, p. 1) elaborate, through the notion of dispositif, how the critical turn makes it possible to reveal geopolitics and power relations involved in studying place names. Puzey and Kostanski (2016) contend that names can signify profound identities, act as elements of attachment and dependence, and mirror communal values and social customs, while working as powerful elements of inclusion and exclusion. Consequently, place naming in the selected study area signals prevailing discourses that echo diverse representations, actors, and these have implications in social relations.

Critical analyses depart from earlier toponomastics studies that centred on etymology and historical-culturalist methodologies that produced "suspiciously innocent and bloodless accounts of history" (Berg et Vuolteenaho, 2009, p. 6). Intricately analysing power relations in place naming practises echoes (Berg et Vuolteenaho, 2009) when they maintain that the apolitical treatment of toponyms has had negative implications for marginalised groups. A-critical studies are argued to encourage subdual of minority languages and project conflict-free linguistic relationships in past which was unlikely the case. In Africa, they have long supplanted local vocabularies through colonial "christening tendencies" (see Njoh, 2016). Therefore, need arises to embrace a critical view that throws light on how place naming practices can be main stations of "entanglements" where multifaceted "identity relationships of gender, race, age and culture" (Milani, 2014, p. 225) intersect and contest with each other in the broader system of representation in Zimbabwe.

13 Tucci, Ronza, and Giordano (2011, p. 370) point out that the traditional focus on the etymology and taxonomy of place names "has been replaced by a new concern in the authoritative act of naming as a social practice embedded in social and political struggles". This is what they call the 'critical turn' in toponymy studies. This critical turn is marked by an important new interest in the politics of naming by which essentialist claims to affixing stable identities to particular spaces that were implicit in the traditional scholarship on place names are exposed and interrogated. Emerging now is 'an exciting new body of research, which situates the study of toponymy within the context of broader debates in critical human geography'. Place naming is now seen as embedding the process of naming "in the struggle between social groups for power and legitimacy". Places are reinterpreted as palimpsests which can be re- and overinscribed, demonstrating that any place-naming regimes are inherently instable and historically contingent. Toponymic inscriptions express and accompany ideological struggles and power shifts. At the same time, analysis of the process of multiple replacement of different regimes of toponymic inscription over long periods of time is still an emerging area of study.

14 Linguistic landscape studies written language in the public space of an area (BenRafael, 2008; Huebner, 2016; Shohamy, 2006; Shohamy et Gorter, 2008; Shohamy et al., 2010). These studies present helpful methodologies in reading the language in the public space of Bindura because plural toponyms are often written in the public space.

The genesis of LL is often attributed to Landry and Bourhis (1997) who examined how the language of public signage was related to aspects of the ethnolinguistic dynamism of francophone high school students in Canada (Shohamy et al., 2010). Landry and Bourhis (1997, p. 23) contend that the LL denotes the conspicuousness and prominence of languages on signs in a given territory. They included in those language objects "road signs, advertising billboards, street names, place names, commercial shop signs, 
and public signs on government buildings" that serve informational and symbolic functions (Landry et Bourhis, 1997, p. 25). Thus, the LL refers to language entities found in the public space, encompassing private signs at private homes, signage with names of streets, shops and schools (Shohamy et al., 2010, p. xiv) and place names, as in our case.

Illustration 1 - Tempered with signage
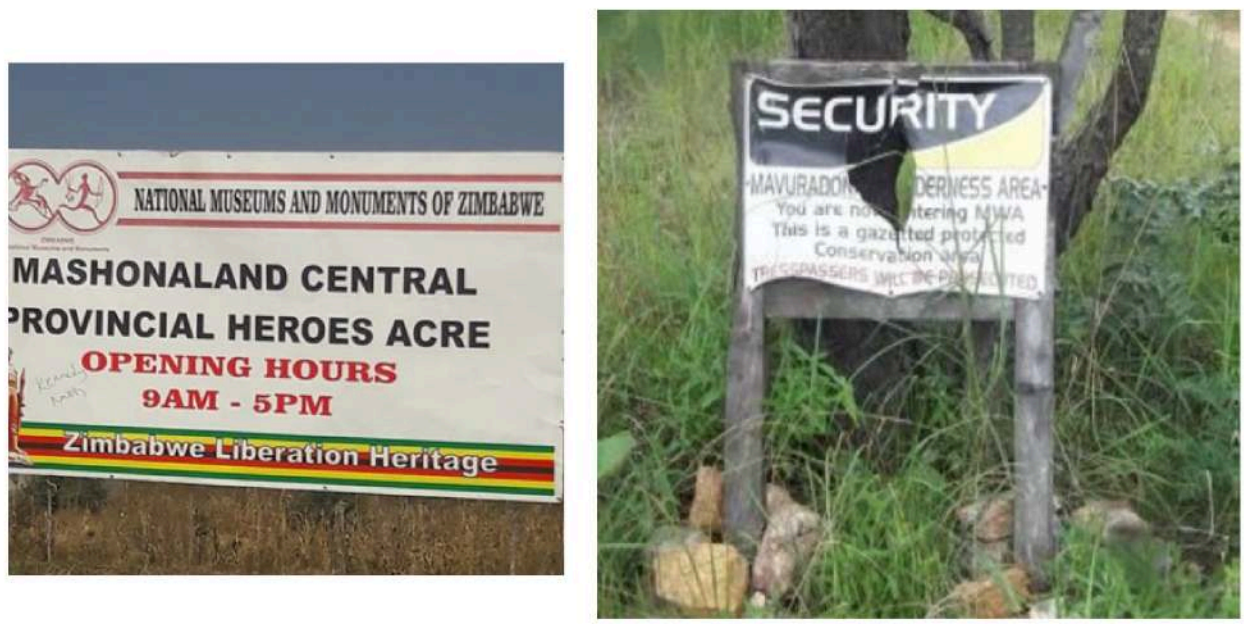

Gauche: informally inscribed "Kennedy Mash".

Authors: Zuvalinyenga, July 2018 (left); Varden Safaris, 2016 (right)

The unit of study in a certain LL is a sign which has the role of being an expressive text which can be read, photographed, probed and linguistically and culturally examined (Al-Athwary, 2017, p. 149), makes it possible to 'read' issues of multiple place naming practices, identity, power and communication in Bindura. Therefore, apart from conveying messages, these public signs illustrate the diversity of language and culture due to the semiotics of the signs (Putz et Mundt, 2018). For example, official street names in Aerodrome suburb in Bindura attest to the nationalist ideology that the government of Zimbabwe champions. Another example is of cases in Bindura and Zimbabwe more generally where people may express displeasure at certain place names by defacing (illustration 1) or destroying the signs that bear them or coining variant names. Cases like these are comprehensible through findings in LL. Pennycook (2010), for example, studies graffiti revealing different motivations for people to inscribe such in the public space. However, coining of variant place names remains understudied, the reason this article explores the phenomenon. Additionally, the wide range of methodologies in LL informed the choice of the mixed method research design taken in this study guided by CDA. Although the methodology area of LL has drawn much criticism, appropriate methodologies are determined by the research questions and the themes pursued in a particular research study.

\section{Results and findings}

17 The study's findings are presented below under the pre-colonial, colonial and postcolonial historical periods. 


\section{Chiefs, hills, herbs, mines and farms: Precolonial and colonial contestations of place naming}

Africa's mining town that got its name in honour of John Wodehouse, the $1^{\text {st }}$ Earl of Kimberley on 5 July 1873 (Roberts, 1976). Kimberley Reefs ${ }^{1}$ changed to Bindura in 1913 when the railway arrived. The railway was a facilitator of colonialism, especially as the basis of capitalist extraction and expansion. (Cf. Walter Rodney, 1972. How Europe Underdeveloped Africa). Thus, the etymology of Bindura is thus already implicated with colonial exploitation and dispossession. This is explicit in the name Kimberly reefs, linking it to South Africa's diamond and gold mining centres. This is a reminder that Zimbabwe (then Rhodesia) began as a British South Africa Company (BSAC) venture intent on finding and exploiting the Second Rand (Van Onselen, 1976). When this Second Rand did not materialise, mining centres and farms dispersed across the country. Bindura is one such product of the failed quest for the Second Rand. Bindura is an anglicised Shona phrase, pindura mhuka, meaning, "turn the game" (Bindura Municipality website). Bindura is not an exception. Other Zimbabwean towns whose names were anglicised during colonial times are Umtali (real name Mutare), Gwelo (Gweru), Marandellas (Marondera), Gatooma (Kadoma), and Que Que (KweKwe), among others. One interview participant however suggested that Pindura Hill is where the anglicised name Bindura is derived. They said the hill was named pindura ("turn") because it had herbs that were used by the ancestors to turn the gender of an unborn child mainly from a girl to a boy since boys were more desirable in the patriarchal society.

20 A colonial heritage of Bindura is seen in the mines extracting cobalt, copper, and nickel, as well as cotton, tobacco and maize farms that are dotted in the area. These industries required labour resources that far exceeded the supply capacity of the province or even the country (see Van Onselen, 1976), thus offering employment opportunities in Bindura to people from throughout the country and across the globe. There were differences between migrant labour and cheap labour (often African) vs expatriate (often white and well-to-do). This has resulted in the area being multilingual and multicultural because of people who spoke different languages converging in Bindura.

21 Farming and mining history of the place is notable in that the place was established and popularised by these activities and the many farms and mines that fill the landscape.

EchoGéo, 53 | 2020 
Illustrations 2 A et B - Mining activities during early 1900s that gave Kimberley Reef its identity
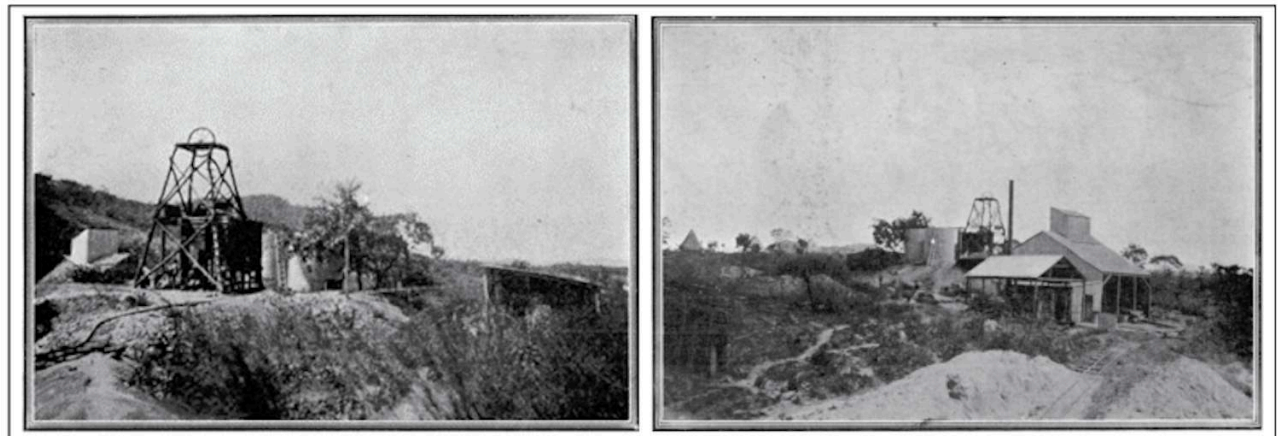

Left: A. A mill at Hay Gold Mine.

Right: B. Part of the surface of the Hay Gold-mining Company.

Credit: Fivenine online archive, 2019

Illustrations 2 C et D - Mining activities during early 1900s that gave Kimberley Reef its identity

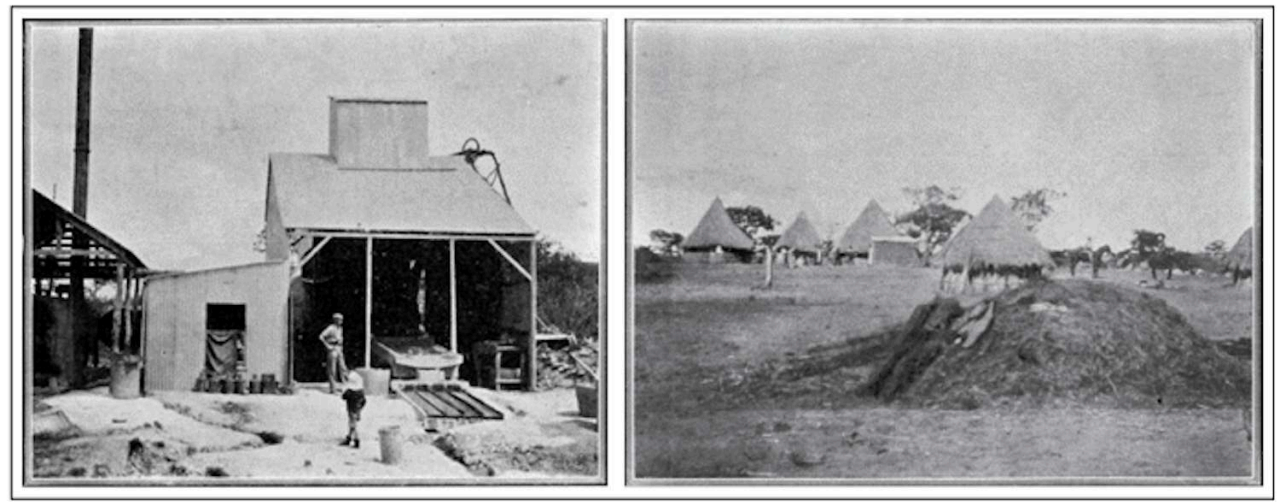

Left: C. A somewhat primitive milling plant that was used to take out gold by George Hay Rattary and colleagues.

Right: D. A compound of the black workers at Hay Mine.

Credit Fivenine online archive, 2019.

Notable events in the place names include Hay Mine, which was pegged by George Hay Rattary in 1908 close to Kimberley Mine. There is also Hay Street, named in his honour. He later sold the mine to Hay Gold Mining Company in July 1910 and moved to Kingstone farm where he became a farmer. The setting up of mines and farms is important to the identity of the place, people who "pioneered" these were honoured by having places (especially streets) named after them. The identities emerging from the infrastructure of mines and farms is tied to the exploitation of cheap mine and farm labour, which started in colonial times and continues in mutated forms today. Use and mention of such names implicates both Bindura and the speaker with this exploitation. These toponymic inscriptions also express the wedge that existed and still exists between mine owners and expatriate staff (mostly white) on the one hand and their exploitable and disposable "cheap" labour employees (commonly Africans). The cheap labour, we can see, stayed in mine compounds (Fig 4). There are significantly fewer whites today, and the wedge persists in the differences in the spatial concentration of poorer black residents in the high-density townships and locations (and farm compounds) while the well-to-do residents stay in low density areas of Bindura such as 
Hospital Area, Shashi View, Claverhill Heights, Greenhill Heights, and in the farm houses.

\section{Post-independence Second Chimurenga and Third Chimurenga place naming}

The War of Liberation (Chimurenga) is commemorated in Bindura where streets, buildings (illustration 3) and places are named after events in the war, nationalists and war veterans. For example, all the street names in Aerodrome suburb are named after war veterans and memorialise the War of Liberation. In the CBD, there is Robert Gabriel Mugabe Way which was formally known as Main Street, Emmerson Mnagagwa Street which was Atherstone Road until 21 November 2019, Chenjerai Hunzvi Street and Border Gezi Avenue. This naming pattern has given Bindura a nationalist outlook that also prevails throughout the country, emphasizing the importance of independence and decolonisation efforts the Zimbabwean government has been pursuing since 1980 .

Illustration 3 - Official signage at a government office complex

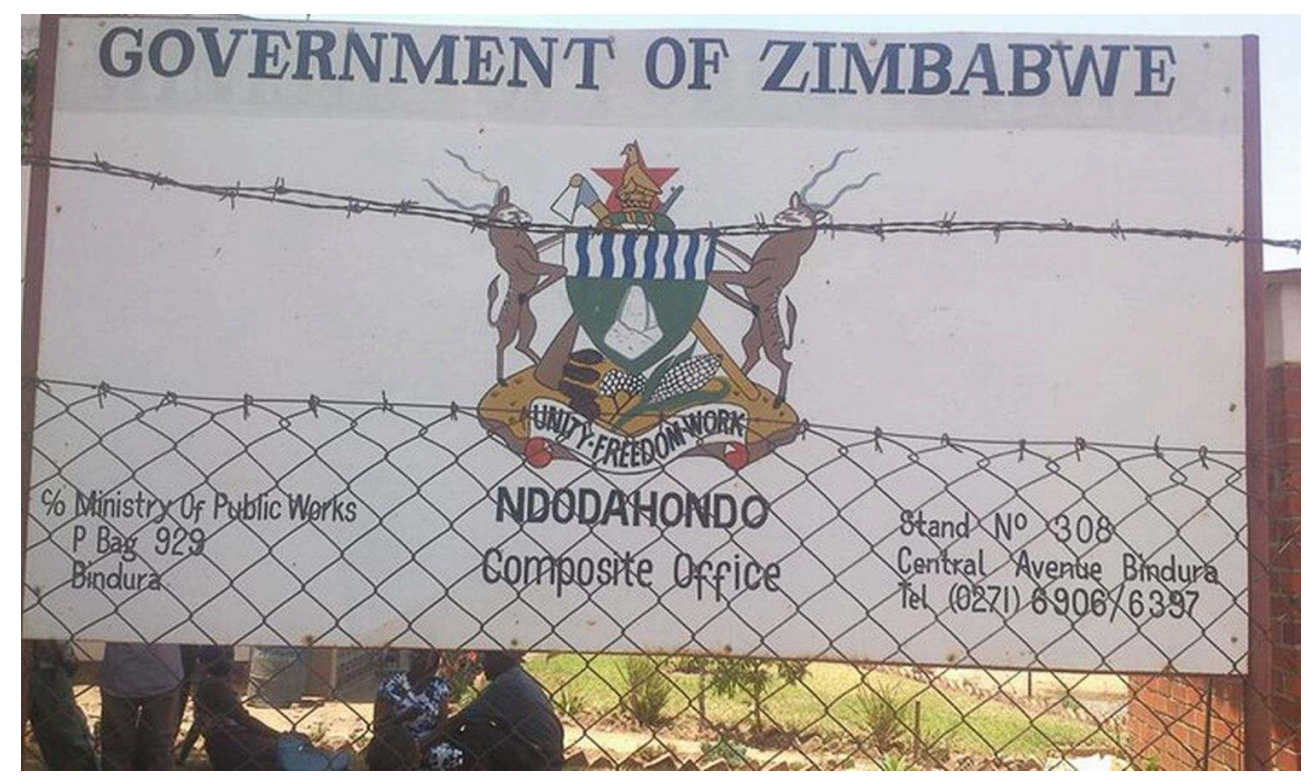

Author: Zuvalinyenga, July 2018.

Segregation of races is evident in the existence of suburbs bearing different identities due to their names, demographic compositions and class categories. On one hand, there is a low-density suburb commonly known as the Hospital Area, kumayadhi ("the place of big yards"), KuHospapa (slang for Hospital), KuChipatara (Shona for Hospital), or KumaDale-dale (affluent suburb in slang), which was mainly for white residents if they were not at their farms. ${ }^{2}$ Due to the enactment of legislation that encouraged separate development for different races during the colonial period, there were suburbs for the different races in Zimbabwe and Bindura was no exception (Fitzmaurice, 2015; Kinloch, 2003). The Hospital Area was largely a white area and its street names attest to this, out of fifty-four streets that have names other than being numerical, only eight are in Shona. Moreover, the eight are anglicised and given a European outlook as they are referred to as "drives," "views," "circles," "closes" and avenues, examples include Msasa Drive, Mazowe Close and Shashi View Road. On the other hand, there is Chipadze, 
which is a black township that was set-up for black people to provide labour in the factories and to work for white people in their homes as gardeners and house helpers. The name Chipadze itself is of an indigenous chief and street names are in Shona commemorating local people (Musvosvi Street and Kashangura Street), local flora (Mukuyu Street) and fauna (Bimha Street). Chipadze and other high-density suburbs are also known as ghettos or Baghdadi due to their run-down outlook, over-crowdedness and high crime rates (Zimbabwe Republic Police Report, 2019).

Bindura has a rural hinterland under the management of Bindura Rural District Council (BRDC). This hinterland comprises of communal areas that were put in place by the enactment of the Land Apportionment Act of 1963 during the colonial times, and which were the locus of the Fast Track Land Reform Programme (FTRLP) that began in 2000. Thus, today the BRDC encompasses some of the areas that were commercial farms before the land reform (BRDC website, 2017). The important link with colonial land dispossession and the FTRLP makes Bindura an important site for toponymic inscription and re-inscription. Examples of renamed farms and rural or resettlement areas include SOS Farm, previously known as Maizelands Farm, Saimona Farm now Matangira Farm, and Dawmill Farm now Musanhi Farm. Further, contentious and exploitative relationships between farm owners and farm workers have persisted since the colonial period, through independence and to the present after the land resettlements which commenced in the year 2000 (Helliker et Bhatasara, 2018; Kufandirori, 2015).

The rural hinterland of Bindura that was birthed by colonialists who drove away indigenes from their land to semi-arid "reserves" is evident in the place names of Chief Msana and Chief Masembura communal areas. In these areas, there are villages that take their names from topographical features such as mountains, rivers as well as from events, flora and fauna. Under this category there are place names such as Manhenga ("the feathers") which takes its name from the Manhenga Mountain range, Rupakwe ("a place where the mermaids sun-bask") - officially known as Paradise Pools, but locals refer to it as Rupakwe and Wayerera ("you have been swept away [presumably by the river Nyaure]"). Soils in these areas are not productive, therefore, since people depend on farming for a living; there has been urban migration for the youths, leaving the old and frail in these communal areas. This has resulted in the areas being looked down upon and given derogatory slang names such as "kumarunyazi" (underdeveloped area) "kumapfanya" (a filthy place, ideal for lice to breed that will require people to squash them) or "kuBurkina Faso" (anything backward). However, there are also people who have grown fond of their rural homes and call these areas affectionate names such as "kumusha" (home), "kurukuvhute" (where the umbilical cord is) and "kuroots" (where my roots are) indicating that they are attached to these places.

\section{Informal and Slang Place naming}

Bindura also means "a bitch in season" in Shona, and this association of the name is used pejoratively to pour scorn on the perceived immoral behaviour attributed to some of the town's residents. People of a conservative bent opt to ignore the vulgar association and connotation of the town's name. The youth use slang to refer to Bindura as Binzburg, Bindvegas, B-town or Bind-Angeles. This is a trendy way of 
likening the sleepy farming and mining town to metropolis of the world such as Johannesburg, Las Vegas, H-town (Harare) and Los Angeles.

Unofficial names are often used by the youths in places where there are no official names as well those that have names that do not resonate with the inhabitants. Mabhodhoro (Kingstone Farm), Jompiyi (Acadia Estates), Dzedzereke (Kudu Vlei Farm) and Ridhi (Hinton Farm) are examples unofficial names given to farms by farm workers who will be forging solidarity against their employer. Both young and old people use these names. Shopping centres also have official and unofficial names, with older people referring to them by their official names while youths use slang toponym such as "Kanos bombistombi" (Kanosvamhira's Bottle Store) and "magrosimbi" (at the grocer's).

Public transport operators and users have coined many unofficial names for bus stops. The official names are long (Tendai Hall Bus Terminus is shortened to either TH or THall) and located at inconvenient locations, therefore people come up with their own such as "pamarara" (at the garbage heap), "pamasimbi" (at the iron rods), "pamaChina" (at the Chinese) and "pamusawu" (at the Musawu tree). The power of slang toponyms is noticeable here when language is manipulated for the sake of in-group communication. This involves secrecy as well as fun and competition - the fluid linguistic practices thus serve different purposes at the same time. Therefore, the playful language is not only used to conceal and exclude others, but also to engage in linguistic creativity and express identity (Zuvalinyenga, 2020).

\section{Discussion}

Multiple place naming practices in Bindura elicit insights on the place and people's history, events, culture, identities, languages and socio-political standings, attesting to the diverse ways in which people relate to given spaces. The study found that the interrelationships between place naming practices, identity and power are complex as there are diverse toponymic situations in Bindura. There are official toponyms that coexist with unofficial ones. In most cases, the unofficial toponyms are used and are in conflict (symbolically and physically competing for space and recognition) with the official ones. Due to the fluidity of identities and histories, this fluidity is also transformed and inscribed onto place naming, making the latter a relational and temporal activity that is determined by various internal and external factors. It is in this flux that various actors are either empowered or disempowered to affirm their identities. Authorities deploy the legislative apparatus to inscribe toponymies heavily inflected with political party ideologies and normative identities through officially naming places. This use of political office and legislative frameworks may disempower those without authority to legislate names. However, the marginalised are not passive observers. Instead, they use language and make meaning of the world in and on their own terms. In Bindura, for instance, the marginalised coin and use unofficial toponyms which co-exist harmoniously, ambivalently or uneasily with the official names. This use of unofficial place names then becomes both a means of practical communication of place as well as a symbolic act of asserting one's identity (Ainiala et Lappalainen, 2017; Ainiala et al, 2016; Ainiala et Östman, 2017; Ainiala et al., 2012; Vuolteenaho et al, 2019). Closely related groups use the informal, context-specific and preferred unofficial place names. In this way, unofficial toponymic practices become a way of regulating social relations because individuals can express themselves in their own terms, or in terms 
not limited to official inscription. Some of these informal names incorporate resistance through slang and humour. The humour present in most of these unofficial toponyms, for example, helps in easing tensions and encourages social bonds (Zuvalinyenga, 2020). Unofficial toponyms can foster inclusivity and integration in multilingual, multicultural societies because, among other things, they afford and give value to individuals and various social groups' means of expressing who they are in the most preferred manner, and enable them to claim and get their rights to the city through identity mobilisation.

31 The patriarchal outlook of both the colonial and post-colonial eras is also evident in place naming practises. The rural authorities and urban naming committees often comprise men. Farm/mine owners who name these features are men and this has led to the men commemorating themselves or their male colleagues and heroes at the expense of women. In the rural areas, there are no female chiefs or village heads and these are the decision-making people, therefore women are left out. The council committees are also made up of men. Many farm and mine owners were/are male, thus most of these bear masculine names, Hay Mine was named after George Hay Rattray, as shown above, while Jesmond Dean Estates was named after its male owner (Zuvalinyenga, 2018).

Overall, place names of Bindura urban and its rural hinterland give the area and its people various and complex identities, showing the different ways different people relate to it. Histories of pre-colonial, colonial and post-colonial people, activities, cultures, languages and behaviours are made clear from place naming. Place names adapted from flora and fauna connote to the relationship early inhabitants of Bindura had with the environment. The San and the Khoi who first inhabited Zimbabwe were hunters and gatherers (Garlake, 1982, 1987, 1990, 1995; Mlambo, 2014) and left traces of their lives through naming places out of nature. Colonialism is memorialised by European names of farms, mines and streets (especially of the Hospital Area). The postindependence era is exemplified by (re)naming of entities to give them an identity that commemorates the War of Liberation and nationalist ideology, with street names in the $\mathrm{CBD}$ and suburb of Aerodrome memorialising the war and those who participated in it.

Place names are closely connected to a place and people's identities, at the same time exhibiting political (re)presentations of the different actors and users. Different identities of Bindura can be traced throughout the pre-colonial, colonial and postcolonial periods from the way places are named. Place names such as Manzou ("the elephants") [Mazowe; linked with the history of Mbuya Nehanda; lately with Grace Mugabe's farm-grabbing], Chemhofu ("of the eland") and Chevadzimu ("of the ancestors") are linked to the pre-colonial period and the San/Khoi, early inhabitants who depended on the environment for survival. To orient to place and show their appreciation of what nature was giving them, they often named places describing flora and fauna, events, people and activities. In this sense, the hunter-gatherer identity is noticeable. However, even though oral narratives support this view, shortcomings are notable in that greater reliance is placed on individual memories, which are prone to biases and distortions. Nevertheless, archaeological evidence supports the former view (Garlake, 1987, 1990).

The colonial period that brought fortune hunters in search of gold, came with the opening of mines and farms, industries that give Bindura its current identity. For instance, the opening of Kimberley Reefs Mine in 1901 marked the onset of organised 
modern settlement in the area. Other mines were subsequently pegged with some miners changing business to take up farming. The colonial period also brought forth tussles in race relations and these contestations manifest in place naming. Examples are the existence of official and unofficial corpuses of place names where authorities give official names through laws, but residents who do not relate to those names coin their own.

The post-colonial period is characterised by decolonisation and reclamation of lost land, culture, language and identities. Nationalist ideologies and identities followed during the War of Liberation are noticeable in the linguistic landscape where heroes of the war are honoured with places named after them. Other languages (Shona, Ndebele, Chewa, Nyanja and slang) that had been peripherised are now being used both in formal and informal place naming. However, inequality is glaring when it comes to gender imbalances and representation of minorities in the linguistic landscape. Overall, names of a place are a window to the way the practice is often used to legitimise particular political authority and social hierarchies at the expense of powerless members. However, the marginalised, through coining and use of variant and unofficial nomenclature overtly/covertly contest the marginalisation.

\section{Conclusion}

This article demonstrated the use of multiple toponyms in the town of Bindura in Zimbabwe. It noted how these uses point to the co-existence and ongoing negotiation, contestation and articulation of varied identities in Bindura on the basis of history, age, class, race, gender, ideology, language, culture, communication, and power. The article traced instances of place naming and the conflicting political, social and ideological values that underpinned such naming. As a result, the shifts and continuities of different toponymic regimes and hegemonic discourses that took over one after the other over time are explored in relation to the pasts, histories, present-day experiences, and conflicting ideologies which they evoke. Tucci, Ronza and Giordano's study of the "layering (of) the toponymic tapestry", whereby toponyms reflect a place's long and contested social and political history, informed the study. The toponymies and toponymic inscriptions reveal the operation of various discourses, identities and social representations that are traced from precolonial times to the present. Through the study of names, we get a window into the events or behaviours of a particular place and its inhabitants.

\section{BIBLIOGRAPHY}

Ainiala T., Lappalainen H., 2017. Orienting to norms: Variability in the use of names for Helsinki. In T. Ainiala, J.-O. Ostman (ed.), Socio-onomastics: The pragmatics of names. London, New York, John Benjamins Publishing Company, vol. 275, p. 129-154. 
Ainiala T., Lappalainen H., Nyström S., 2016. Slang name or official name? Suburb names as mirrors of urban identities in eastern Helsinki. Yhdyskuntasuunnittelu, vol. 54, nº 2, p. 41-59.

Ainiala T., Östman J.-O. (ed.)., 2017. Socio-onomastics: The pragmatics of names. Amsterdam, Philadelphia, John Benjamins Publishing Company.

Ainiala T., Saarelma M., Sjöblom P., 2012 [e-book 2016]. Names in focus: An introduction to Finnish onomastics. Norderstedt, BoD-Books on Demand.

Al-Athwary A. A., 2017. English and Arabic Inscriptions in the Linguistic Landscape of Yemen: A Multilingual Writing Approach. International Journal of Applied Linguistics and English Literature, vol. $6, \mathrm{n}^{\circ} 4$, p. 149-162.

Ameel L., Ainiala T., 2018. Toponyms as Prompts for Presencing Place. Making Oneself at Home in Kjell Westö's Helsinki. Scandinavian Studies [En ligne], vol. 90, n 2, p. 195-210. DOI: https:// doi.org/10.5406/scanstud.90.2.0195

Azaryahu M., 1996. The Power of Commemorative Street Names. Environment and Planning D: Society and Space [En ligne], vol. 14, n 3, p. 311-330. DOI: https://doi.org/10.1068/d140311

Azaryahu M., 2009. Naming the past: The significance of commemorative street names. In Critical toponymies: The contested politics of place naming, Surrey, Ashgate Publishing Company, p. 53-70.

Azaryahu M., 2011. The critical turn and beyond: The case of commemorative street naming. ACME: An International E-journal for critical geographies, vol. 10, $\mathrm{n}^{\circ}$ 1, p. 28-33.

Ben-Rafael E., 2008. A sociological approach to the study of linguistic landscapes. In E. Shohamy D. Gorter (ed.), Linguistic Landscape, London, Routledge Publishers, p. 48-62.

Berg L. D., Vuolteenaho J. (ed.)., 2009. Critical Toponymies: The Contested Politics of Place Naming. Farnham, Ashgate Publishing Company.

Bigon L., 2008. Names, norms and forms: French and indigenous toponyms in early colonial Dakar, Senegal. Planning Perspectives, vol. 23, n 4, p. 479-501.

Bigon L., 2016. Place names in Africa: Colonial urban legacies, entangled histories. Switzerland, Springer International Publishing.

Bindura Municipality, 2016. URL: https://binduramunicipality.co.zw/

Bindura Rural District Council, 2016. URL: https//www.bindurardc.co.zw/

Bogetić K., 2013. Normal straight gays: Lexical collocations and ideologies of masculinity in personal ads of Serbian gay teenagers. Gender and language, vol. 7, n 3, p. 333-367.

De Fina A., 2006. Discourse and identity. In A. De Fina, D. Schriffin, M. Bamberg (ed.), Discourse and identity, Cambridge, Cambridge University Press, p. 263-282.

Dodo O., Musorowegomo C., 2012. Political intolerance, diversity and democracy: Youth violence in Bindura Urban, Zimbabwe. American International Journal of Contemporary Research, vol. $2, \mathrm{n}^{\circ} 6$, p. 134-143.

Dube L., 2018. Naming and renaming of the streets and avenues of Bulawayo, a statement to the vanquished by the victors? Nomina Africana: Journal of African Onomastics, vol. 32, $n^{\circ} 2$, p. 47-55.

Firth J. R., 1957. Papers in Linguistics 1934-1951. London, Oxford University Press.

Fitzmaurice S., 2015. Ideology, race and place in historical constructions of belonging: the case of Zimbabwe. English Language and Linguistics, vol. 19, № 2, p. 327-354. doi:10.1017/

s1360674315000106 
Fivenine [Online Archive]. URL: https://www.fivenine.co.uk/family_history_notebook/ background/rhodesia/bindura/Mines/hay_mine.html

Garlake P. S., 1982. Prehistory and ideology in Zimbabwe. Africa, vol. 52, nº 3, p. 1-19.

Garlake P. S., 1987. The painted caves: an introduction to the prehistoric art of Zimbabwe. London, Modus Publications.

Garlake P. S., 1990. Symbols of potency in the paintings of Zimbabwe. The South African Archaeological Bulletin, p. 17-27.

Garlake P. S., 1995. The hunter's vision: The prehistoric art of Zimbabwe. London, British Museum Press

Górny K., Górna A., 2019a. After decolonization: Changes in the urban landscape of Platô in Praia, Cape Verde. Journal of Urban History, 45, n 6, p. 1103-1130.

Górny K., Górna A., 2019b. Street names in Dakar-Plateau: a colonial and post-colonial perspective. Planning Perspectives, p. 1-24.

Gorter D., 2018. Methods and techniques for linguistic landscape research: About definitions, core issues and technological innovations. In M. Putz, N. Mundt (ed.), Expanding the linguistic landscape: Linguistic diversity, multimodality and the use of space as a semiotic resource, Bristol, Multilingual Matters, p. 38-57.

Helliker K., Bhatasara S., 2018. Inside the land occupations in Bindura District, Zimbabwe. African Studies Quarterly, vol. 18, $\mathrm{n}^{\circ}$ 1, p. 1-17.

Helliker K., Chiweshe M. K., Bhatasara S., 2018. The political economy of livelihoods in contemporary Zimbabwe. London, Routledge Publishers.

Hodge B., 2012. Ideology, Identity, Interaction: Contradictions and Challenges for Critical Discourse Analysis. Critical Approaches to Discourse Analysis across Disciplines, vol. 5, nº 2.

Huebner T., 2016. Linguistic landscape: history, trajectory and pedagogy. Manusya: Journal of Humanities, vol. 19, $\mathrm{n}^{\circ}$ 3, p. 1-11.

Kadenge M., Mugari V., 2015. The current politics of African languages in Zimbabwe. Per Linguam: A Journal of Language Learning Per Linguam: Tydskrif vir Taalaanleer, vol. 31, n² 2, p. 21-34.

Kinloch G. C., 2003. Changing racial attitudes in Zimbabwe: Colonial/post-colonial dynamics. Journal of Black Studies, vol. 34, n 2, p. 250-271.

Kufandirori J. T., 2015. Fast Track Land Reform in Matepatepa commercial farming area, Bindura District: Effects on farm workers, 2000-2010. Master Thesis, University of the Free State South Africa.

Landry R., Bourhis R. Y., 1997. Linguistic landscape and ethnolinguistic vitality: An empirical study. Journal of language and social psychology, vol. 16, n 1, p. 23-49.

Mamvura Z., 2014. A Sociolinguistic Analysis of School Names in Selected Urban Centres During the Colonial Period in Zimbabwe:(1890-1979). PhD Thesis, University of South Africa.

Mamvura Z., Mutasa D. E., Pfukwa C., 2017. Place naming and the discursive construction of imagined boundaries in colonial Zimbabwe (1890-1979): The case of Salisbury. Nomina Africana: Journal of African Onomastics, vol. 31, $\mathrm{n}^{\circ}$ 1, p. 39-49.

Mangena T., 2018. Rhodes, Mugabe and the politics of commemorative toponyms in Zimbabwe. Geopolitics, N/A, p. 1-22. 
Milani T. M., 2014. Sexed signs-queering the scenery. International Journal of the Sociology of Language, 2014, $\mathrm{n}^{\circ} 228$, p. 201-225.

Mlambo A. S., 2014. A history of Zimbabwe. Cambridge, Cambridge University Press.

Mlambo M., 2009. A survey of the language situation in Zimbabwe. English Today, vol. 25, $\mathrm{n}^{\circ} 2$, p. 18-24.

Mushati A., 2013. Street naming as author(iz)ing the collective memory of the nation: Masvingo's Mucheke surbub in Zimbabwe. International Journal of Asian Social Science, vol. 3, n 1, p. 69-91.

Njoh A., 2007. Planning power: Town planning and social control in colonial Africa. London, University College London Press.

Njoh A. J., 2009. Urban planning as a tool of power and social control in colonial Africa. Planning Perspectives, vol. 24, n 3, p. 301-317.

Nyambi O., Mangena T., Pfukwa C. (ed.)., 2016. The Postcolonial Condition of Names and Naming Practices in Southern Africa. Cambridge, Cambridge Scholars Publishing.

Pennycook A., 2010. Spatial narrations: Graffscapes and city souls. In A. Jaworski, C. Thurlow (ed.), Semiotic landscapes: Language, image, space, London, A and C Black, p. 137-150.

Pfukwa C., 2018. (Re) writing an urban landscape: Street names in Harare's CBD after 1980. Nomina Africana: Journal of African Onomastics, vol. 32, $n^{\circ} 1$, p. 37-45.

Puzey G., Kostanski L. (ed.)., 2016. Names and Naming: People, Places, Perceptions and Power. Bristol, Multilingual Matters.

Roberts B., 1976. Kimberley: Turbulent city. Cape Town, New Africa Books.

Rose-Redwood R., Alderman D., Azaryahu M., 2009. Geographies of toponymic inscription: new directions in critical place-name studies. Progress in Human Geography, vol. 34, n 4, p. 453-470. doi: 10.1177/0309132509351042

Rose-Redwood R., Alderman D., Azaryahu M. (ed.)., 2018. The Political Life of Urban Streetscapes: Naming, Politics, and Place. London, NewYork, Taylor \& Francis.

Rose-Redwood R., Kim S.-B., 2020. Street naming and power. In A. Kobayashi (ed.), International Encyclopedia of Human Geography (2nd ed.), Ontario, Elsevier Ltd, p. 55-60.

Rose-Redwood R., Vuolteenaho J., Young C., Light D., 2019. Naming rights, place branding, and the tumultuous cultural landscapes of neoliberal urbanism. Urban Geography, vol. 1-15.

Shakespeare W., 2003. Romeo and Juliet. Cambridge, Cambridge University Press.

Shohamy E., 2006. Language policy: Hidden agendas and new approaches. London, Routledge Publishers.

Shohamy E., Gorter D., 2008. Linguistic landscape: Expanding the scenery. London, Routledge Publishers.

Shohamy E. G., Rafael E. B., Barni M. (ed.), 2010. Linguistic Landscape in the City. Bristol, Buffalo and Toronto, Multilingual Matters.

Sihlongonyane M. F., 2015. Empty signifiers of transformation in participatory planning and the marginalization of black people in South Africa. Planning Practice and Research, vol. 30, $\mathrm{n}^{\circ} 1$, p. 83-100.

Tucci M., Ronza R.W., Giordano A., 2011. Fragments from many pasts: layering the toponymic tapestry of Milan, Journal of Historical Geography, n³7, p. 370-384. 
Varden Safaris, 2016. Biodiversity, conservation and cultural heritage importance of the Mavhuradonha Wilderness Area in the Muzarabani district, northern Zimbabwe. Harare: Black Crystal Ltd.

Vuolteenaho J., Lappalainen H., Ainiala T., 2019. A slightly slummier area? Negotiations of placebound identities through social spatializations and unofficial toponyms. Journal of Sociolinguistics, vol. $23, \mathrm{n}^{\circ} 2$, p. $140-162$

Wanjiru M. W., Matsubara K., 2017. Street toponymy and the decolonisation of the urban landscape in post-colonial Nairobi. Journal of Cultural Geography, vol. 34, n 1, p. 1-23.

Wodak R., 2015. Critical Discourse Analysis, Discourse-Historical Approach. In K. Tracy, C. Ilie, T. Sandel (ed.), The international encyclopedia of language and social interaction, London, John Wiley \& Sons Inc., vol. 1, p. 1-14

Woodman P., 2012. The Great Toponymic Divide. Reflections on the definition and usage of endonyms and exonyms, Warszawa, Head Office of Geodesy and Cartography

Zimbabwe National Statistics Agency., 2015. Bindura: Population Census. Harare, Government Printers.

Zotzmann K., O'Regan J. P., 2016. Critical discourse analysis and identity. In S. Preece (ed.), The Routledge handbook of language and identity, Abingdon, Routledge, p. 139-154.

Zuvalinyenga D., 2018. The gendered linguistic landscape: A case study of street names in Bindura, Zimbabwe. Paper presented at the International Conference on Gender, 17-19 July 2018, University of Zimbabwe, Harare.

Zuvalinyenga D., 2020. "The lion has learnt to tell its side of the story". Reframing identity, power and place through humour: The case of slang toponyms. Paper presented at the 26th Australasian Humour Studies Network (AHSN) Griffith University, Brisbane, Australia.

\section{NOTES}

1. Kimberley itself is a transfer place name from the Northern Cape, South Africa that was given in honour of (John Wodehouse, the $1^{\text {st }}$ Earl of Kimberley) on 5 July 1873 (Roberts, 1976). Roberts argues that the Colonial Secretary for the Crown Colony, J. B. Currey, named the place after Lord Kimberley so that it can be easy for the Lord to spell and pronounce. Roberts further argues that the renaming of the place was necessary because the Lord had declined to be associated with a 'vulgarism' such as New Rush or the Dutch name Vooruitzigt, which he could neither spell nor pronounce.

2. The situation is however changing since Zimbabwe's independence and has heighted with the land reform where most white farmers lost the land to indigenous people that are resettling there. Most white people left and continue to leave Zimbabwe. 


\section{ABSTRACTS}

This article examines the layered co-existence and simultaneous use of a complex range of toponyms in the town of Bindura in Zimbabwe. It proposes that the concurrent use of different names for the same place indicates the ongoing negotiation, contestation and articulation of diverse identities in Bindura on the basis of history, age, class, race, gender, ideology, language, culture, communication, and power. The implications of plural toponymies on members of the selected community and their relationship to a place are explored in as far as the toponymies and toponymic inscriptions may be said to reveal the operation of various discourses, identities and social representations that are traced from precolonial times to the present. The article follows Tucci, Ronza and Giordano's study of what they call the "layering (of) the toponymic tapestry" whereby toponyms can be a reflection of a place's long and contested social and political history. Fragments of different toponymic regimes and hegemonic discourses that took over one after the other over time remain inscribed in these place names, thus originating "a complex tapestry" in which different pasts, histories and present day experiences revive and conflicting ideologies and identities co-exist. In essence, names and naming practices of a place gives us windows into the events or behaviours of a particular place and its inhabitants.

INDEX

Keywords: plural toponymies, critical toponymy, identity, discourse, power, communication Subjects: Sur le Champ - Sur le Terrain

\section{AUTHOR}

\section{DORCAS ZUVALINYENGA}

Dorcas Zuvalinyenga, dorcas.zuvalinyenga@uon.edu.au, is a PhD candidate at the University of Newcastle, Australia. 